\title{
TEACHERS STRATEGIES IN ONLINE LEARNING DURING COVID PANDEMIC
}

\author{
N.K.S. Widarini ${ }^{1}$, I.N.A.J. Putra ${ }^{2}$, N.P.E. Marsakawati ${ }^{3}$ \\ ${ }^{123}$ English Language Education, Universitas Pendidikan Ganesha, Singaraja \\ e-mail: komangsriwidarini@gmail.com , adijayaputra@undiksha.ac.id, marsakawatiera@undiksha.ac.id
}

\begin{abstract}
For many teachers the use of the online teaching strategies is quite challenging. They considered that it was not easy to be applied because the teachers were still learning about e-learning. To cope with the problems various strategies were used by teachers in online learning to achieve learning objectives. This research aimed to investigate strategies that teachers used and challenges that they encountered when they were delivering English online learning. The research design used in this study was qualitative case study. The research subjects were three English teachers who were teaching at public junior high schools in Tabanan District. The data were collected by using observations and interviews. The data analysis technique used was descriptive qualitative. It was found that teachers implement various strategies, which include the use of Google form, Google Meet, quizzes, and video. Google meet was found to be the least frequently used platform in online learning because most teachers only used online chat. Teachers found some challenges: they were internet connection, unresponsive students, and problems with the operation of the equipment at the beginning of the pandemic.
\end{abstract}

\section{Keywords: Covid Pandemic; Online Learning; Teacher's Strategies, Teacher's Challenges}

\section{INTRODUCTION}

The emergency response period for the Covid-19 pandemic has not yet ended, making the public even more restless. No exception for educators who have to be extra prepared for everything online learning. This is to ensure that teaching and learning activities continue, even though students are at home. This is under the Minister of Education and Culture of the Republic of Indonesia regarding Circular Number 4 of 2020 concerning Implementation of Education Policies in the Emergency of the Spread of Coronavirus Disease (Covid-19) (Atsani, 2020). The solution, teachers are required to design online teaching strategies as an innovation in the teaching process.

New online teaching strategies produce many obstacles for the teachers. It is not easy to apply because the teachers are still learning about e-learning. They encountered some obstacles when they implemented it. Moreover, teachers have their perception to implement online learning. Teacher perception becomes an important thing. Satrianingrum and Prasetyo (2021) stated that teacher's perception of the impact on student's is the lack of availability of facilities and infrastructure, difference environments when studying in the classroom and studying at home, which affect the enthusiasm of students. Teachers and students feel a burden on internet quotas, especially if they are in an area that is disturbed by signals, monitoring of child development is limited, teachers feel as free as in class.

Therefore, various strategies were used by teachers in online learning to achieve learning objectives. There were various types of teaching strategies. One of them is Blended Learning. This type of strategy was proposed by Istiningsih and Hizbullah (2015). According to them, the blended learning strategy has 3 components, they are: online learning, face-toface learning, and independent learning. In addition, Lesli Anawati and Arif (2020) identified and described three teaching strategies that teachers implemented during, they are: online chat only, videoconference and mixing online chat and video conference during the teaching and learning process.

The teaching strategies problems occurred at three Junior High Schools in the Tabanan district. Before the Covid-19 pandemic, teaching strategies were planned by the 
English Subject Teachers Conference (MGMP) or the EFL Teachers Coordination Group. EFL teachers use and apply the EFL learning process using the compromised learning strategy in face-to-face interactions at three Junior High schools around Tabanan district. After the Covid-19 outbreak, the Ministry of National Education and Culture transferred the EFL learning process to an online learning platform.

The policy in online learning platforms brings about new challenges and difficulties to three teachers, especially in SMPN 1 Tabanan, SMPN 3 Tabanan, and SMPN 6 Tabanan. Teachers who often teach face-to-face in class suddenly have to teach in the media. Some barriers that are considered ineffective, such as the teachers' provision of learning materials, the technical literacy of the teachers and parents who guide the child, and the child's financial status (Satrianingrum and Prasetyo, 2021). Generally, speaking English as a foreign language teachers may not be familiar with e learning, so there are still many obstacles in the learning process, such as the use of e learning tools for teaching, the knowledge of teachers , time management, and student's motivation (Windiarti and Pratolo, 2019).

\section{RESEARCH METHOD}

The present research was designed by using a qualitative approach particularly a case study research design. This method was selected because it could potray what occured in the real field (Moloeng, 2014) and to describe what was naturally occured in the setting, this research presented data, analyzed and interpreted data. The aim was to provide a systematic and careful description of the EFL teacher's abilities in making strategies in online learning, and obstacles encountered by them.

The study was conducted in three State Junior High Schools in Tabanan District, namely SMPN 1 Tabanan, SMPN 3 Tabanan, and SMPN 6 Tabanan. The schools used the national curriculum with some program strategies for a better learning outcome. The teachers used three languages such as English, Bahasa Indonesia, and Bahasa Bali.

Three EFL teachers were recruited for the research subject. Three of the teachers recruited had experience in finding strategies in online learning for two semesters during the Covid_19 pandemic. Subject 1 teacher for grade 7, subject 2 teachers for grade 9, and subject 3 teachers for grade 8 . All teachers have participated in several online workshops to improve their ability to prepare some material in online learning and have also experimented with online teaching. Two of them have received a teacher competency certificate

The data were collected through observation of online learning to know the teacher's strategies were used, and what obstacles were encoutered in implementing online learning. Unstructured interviews were also conducted with the research subject through Zoom meetings and WhatsApp chats. The data from the interviews were used to cross-check the data resulted from the observations and vice versa.

In terms of classifying the data, Lestiyanawati and Arif (2020) identified and described the strategies applied and the problems encountered by teachers in conducting e-learning during the COVID-19 were applying online chat only, using video conferencing, and combining online chat and video conferencing in the online teaching and learning process. Meanwhile, Windiarti and Pratolo (2019) stated the problem is teachers do not understand elearning, so there are still many obstacles in the learning process such as teaching using elearning tools, teacher knowledge, time management, and student motivation.

This study used the qualitative research model of Miles, Huberman, and Saldana (2014). The data were analyzed at the same time as the four concurrent flows activity, they were: collection, data condensation, data display, and conclusion drawing/verification.

\section{FINDINGS AND DISCUSSION}

From interviews and observations, the strategies used by the teacher in online learning were as follows. 
Table 1. Three EFL Teacher Strategies in Online Learning in Tabanan District from Interviews and Observations

\begin{tabular}{ll}
\hline Teachers & Strategy \\
\hline Subject 1 & Online chat only \\
Subject 2 & Combining online chat and video conferencing \\
Subject 3 & Online chat only \\
\hline
\end{tabular}

The results of the interview and observations are presented in the following.

The conclusion of the strategies used by teachers as shown in the following table.

Table 2. Conclusions of The strategies Used by Teachers

\begin{tabular}{llccc}
\hline No & \multicolumn{1}{c}{ Strategies } & Subject 1 & Subject 2 & Subject 3 \\
\hline 1 & Google Form & $\sqrt{ }$ & $\sqrt{ }$ & $\sqrt{ }$ \\
2 & Quiz & & $\sqrt{ }$ & $\sqrt{ }$ \\
3 & Google Meet & $\sqrt{ }$ & $\sqrt{ }$ & $\sqrt{ }$ \\
4 & Video & $\sqrt{ }$ & $\sqrt{ }$ & \\
\hline
\end{tabular}

Having analyzed data, it was found out that teachers encountered four obstacles, they were: using e-learning tools, teacher knowledge, time management, and student motivation. Each of which was described as follows.

The first obstacle was the used of e-learning tools. The equipment operated at the beginning of the pandemic was bothersome. This could be seen from the confusion of teachers and students when using e-learning tools, while teachers were faced with challenges of making interesting learning. How to get children to submit assignments. Because they could not handle online learning classes. There were even students who did not have cell phones. Also, the obstacle to online learning was the Internet connection, it was difficult to coordinate with unresponsive students. Student enthusiasm and attendance rate getting decreased and teachers could not measure student purely through online tests.

The second obstacle was teacher's knowledge. Every teacher must had good knowledge and good understanding. This was because students' understanding was based on the teacher's understanding of the material and applied it to the classroom. To be successful, colleges must embrace, implement, and adopted technological advancements, including e-learning. Teachers must know how to implement e-learning applications. The teachers still had problems with it. Based on these findings, teachers think that e-learning was still something new, and they still had low awareness of technology. Technology was important to learn. Teachers must had awareness of technology because if they did not know it, they would be confused with e-learning applications. Therefore, teachers must learned the technology that it could be accessed in the teaching process. In this case, the teacher had difficulty in IT. Because online required them to make learning media that uses IT. Obstacles to online learning besides IT, teachers were challenged to make interesting learning, although sometimes their abilities were limited, so they made varied learning. Besides, the teacher was confused. How to get children to submit assignments. Because they could not manage learning in class. The effort by calling the parents of students also did not succed. Actually, teachers learnt more. Regarding the question and answer keys created in the Google form, and the quiz created.

The third obstacle was time management. Time management was one of the teacher's obstacles that had to overcome. Perhaps the best-known context for this term was "personal time management," which refers to a set of habits, rules, and recommendations on how to effectively manage their own time and accomplish as much as possible within a specific time frame as stated by Covey $S$ (1990). The teacher had to be able to manage the time according to the needs of the students. The new learning method (elearning) is more suitable than direct learning. The communication level and comment time are good. As long as the best course planning can clarify the physical conditions for knowledge development (Chen et al, 2006). This means that learning time could be obtained by online learning and offline learning. Based on these findings, the teachers said that learning English needed more practice while the time for one meeting was 100 minutes. Students must learn English by 
using e-learning, but they still encounter problems in implementing the application. They had to be able to devote their time to learning English and operating e-learning applications. Therefore, teachers need to manage time so that students could learn English effectively. Not only learning how to apply e-learning but also learning to practice English. The learning process can be done face-to-face and online learning. It depends on the teachers managing time. In this case, the teachers made learning programs such as annual programs and semester programs that were adjusted to the educational calendar. Then the teacher also adjusts online learning to the school schedule. If the teacher could not teach, then it was moved to another day, to make it more flexible. In addition, the teachers also tried to complete the task, for example, giving assignments during learning hours even though the time was often not suitable to the plan.

The fourth obstacle was student's motivation. Wlodkowski (2005) pointed out, "Compared with traditional classroom methods, students could learn more using computerbased teaching." Student's motivation could be seen in the way the learning process was performed. Macharia and Pelser (2012) pointed out that learning materials that used advanced technologies complement extraordinary insights about the reasons that affected the acceptance of e-learning by students. Technical teaching could increase and decrease student enthusiasm. Another finding from a study, students operated the application, and they faced several obstacles. When they tried to solve a problem, they coud not face it. They felt it did not matter. Hence, student learning motivation could be influenced by where they studied and the tools they used. The teacher was only a facilitator to guide students in using the tools. Student's abilities could also affect operating the tool. At first, students would feel interested, but if there were obstacles their motivation would decrease. In this case, the obstacles to online learning besides IT, teachers were challenged to make interesting learning such as made learning videos, quizzes, game education, or others so that they do not get bored of learning. To increase students motivation, teachers often told stories, for example by saying let's support each other, thank you for submitting assignments on time or hopefully Covid would pass quickly and sometimes even invite students to sing in online learning. To meet the needs of students, the teachers gave opportunities to students by telephone and the teacher willing to be contacted. The teacher tried to tell them to install an application that did not spend much the internet quota. Only allow them to send assignments to WA because they did not have enough quota.

The teaching strategies used in online learning at 3 junior high schools in Tabanan District tend to be the same, they were: online chat only (google form, video, and quizzes) and combining online chat and video conferencing (google form, google meet, video, and quizzes). The first strategy was google form. Google Forms is a Google product that could be used to create online learning tests or assessments. (Taufiq Nur Azis, 2017).It was found that the google form was used by all schools to find out student attendance, some shared it on the WhatsApp Group whose members were teachers and students and some shared it on google classroom. As expressed by Devito in Effendy (2011), interpersonal communicationwas the process of sending and receiving messages between two people or between groups with instant feedback. According to three online EFL teachers during Distance Learning (PJJ) , communication between teachers and students must be well established, therefore the teacher created groups between teachers and students through WhatsApp social media which functions to inform the tasks that must be done, and the time of submission, so that learning targets can be achieved properly, as well as in monitoring the condition of students, whether they fully understand the material and assignments given. The WhatsApp group not only discusses learning but was also interspersed with small talk with the aim therefore, students did not feel bored. In the group, all the subjects put them as friends, so that students could be more careful about the difficulties experienced and avoid boredom.

The next strategy teachers use was Google Meet. One of the obstacles experienced by teachers during Distance Learning (PJJ) was video conferencing. The most difficult challengest was the children who were not active in online classes, on google meet were often late and even absent. As Moorhouse (2020) said during the discussions, some people became silent readers, while the responses from the students were shorter. According to 
Warsita (2014), that interpersonal communication strategies could be carried out in person or using electronic means of communication, such as email, social networks, telephone, interactive computer-controlled video (video conference) and online tutorials using internet connections.When students had entered the meet, the teacher asked students to activate the camera so that the teacher knows that students were present in the virtual class, sometimes some students turn off the camera, so it was not known whether the students were present and listening to the material as described by subject 2 . Therefore, subject 2 made a rule so that students activate the camera, and activate the mute button on the meet application. After subject 2 finished explaining the material, subject 2 activated the unmute button so that students could discuss with the teacher the material that had been explained. Here, the teacher usually took attendance and said something. For example hi, hello, morning, etc. Even teachers often told stories, for example by saying let's support each other, thank you for submitting assignments on time or hopefully Covid would pass quickly, and sometimes even invite students to sing at live meetings. Besides that, the teacher can find out the whereabouts of students directly by asked about their situation. This strategy increased student interest in learning during the COVID-19 pandemic because it was simple and attractive. Simple means were easy for teachers and students to use in the learning process in terms of affordable costs. Interesting means not boring and can promote student learning (E. C. Ningsih, personal communication, May 21, 2020). Similar to research by Lestyanawati and Arif (2020) many other applications could be used as utilization tools to support online classrooms, such as ZOOM, Google Meet, and Facebook.

Furthermore, the strategy used by the teachers in online learning was the provision of videos. Some teaching videos were applied with their ability. For example, learning videos made by themselves, lessons that were recorded and then sent to students, videos from You tube, educational games, gave awards by giving additional grades. Another social media network that could be used in the teaching and learning process is You Tube. Implementing You Tube videos into the classroom showed a great contribution to flexibility in teaching. The use of You Tube in teaching had played an important role in helping students understand the text, had a great impact on student's understanding, and also provided good teaching materials (Almurashi, 2016). Students claimed to be happy with online teaching by watched videos that shared by their teachers and being able to make videos related to the learning activities carried out. Using the learning materials provided by information technology was easier, faster, more interesting and very attractive to students (Cuban, 2018).

The last strategies that teachers used in online learning was quizzes. At the beginning of the pandemic the teachers were confused. How to get children to submit assignments. Because they could not manage online learning class. The effort by calling the parents of students also did not work. Tteachers had to learn more, one of them was to make a quiz that was tailored to their abilities. The quiz application was one of the fun online learning application media that could be accessed by students and teachers easily. Online learning applications used interactive media, such as web tools, to conduct game tests, so that teachers could use them as a practical assessment of learning online courses (Agustina and Rusmana, 2020). The used of interactive online learning media would increase the students learning enthusiasm it become more fun, especially during a pandemic, where various students activities could only be done at home. Purba's research results indicated that the application of online quizzes for learning assessment could increase the concentration of learning in middle grades by 0.45 . Therefore, it could be concluded that the use of online quizzes was effective in learning (Purba, 2019: 38). In line with Guhlin who revealed that the quizzes online learning assessment empowers students to develop their skills. If students could complete the quizzes online and respond quickly, they would earn more points (Yana et al., 2019).

Obstacles in online learning were identified after conducting interviews and observations, such as: using e-learning tools, teacher knowledge, time management, and student motivation. The first obstacle was using e-learning tools. Operated gadgets at the start of the pandemic was bothersome. This could be seen from the confusion of teachers and students in using E-learning tools while teachers were challenged to make learning interesting. How to get children to submit assignments. Because they could not manage 
online learning class. There were even students who did not had cell phones. Akhdar (2006) explained that there were two obstacles, physical or non-physical, that hinder the use of computers in teaching. Online learning should be applied to teachers, because some people are still confused about how to apply it, so there are problems to implement it in teaching. One of the problems with the device was the internet connection. The ability to operate tools was necessary for students. Wong and Looi (2011) investigated the effect of mobile devices on student's learning in operating these devices.

The next obstacles was teacher's knowledge. In this case, the teachers had difficulty in IT. Because online required them to make learning media that used IT. Problem to online learning besides IT, teachers were challenged to make interesting learning, although sometimes their abilities were limited, so they made varied learnings. Besides, the teacher was confused. How to get children to submit assignments. Because they could not manage online learning class. Actually, teachers learnt more. About created questions on google form and the answer keys, and created quizzes. This was consistent with research Agustina \& Rusmana (2020), which showed that online learning implementations where teachers used interactive media (such as web tool ) to create quizzes, could use as a practical assessment in online learning classes.

Time management was another obstacles. In this case, the teachers made learning programs such as annual programs and semester programs that were adjusted to the educational calendar. Then the teachers adjusted it to the online learning school schedule. If the teachers could not teach, then it was moved to another day, to make it more flexible. In addition, the teachers also tried to complete the task, for example, gave assignments grades during learning hours even though the time was often not suitable to plan. "Personal time management" which refers to a set of habits, rules, and recommendations on how to effectively manage their own time and accomplished as much as possible within a specific time frame as stated by Covey S (1990).

The last obstacles was student's motivation. In this case, the obstacles to online learning besides IT, teachers were challenged to make interesting learning such as made learning videos such as quizzes, game education, or others so that they did not get bored of learning. To increase student's motivation, teachers often told stories, for example by saying let's support each other, thank you for submitting assignments on time or hopefully Covid would pass quickly, and sometimes even invite students to sing in online learning. To meet the needs of students, the teachers gave opportunities to students by telephone, and the teacher willing to be contacted. As stated by Wijayanti A et al (2018), the teacher's attention had a very important role in improving and providing understanding to students about the importance of learning, both during the process and after learning takes place. This attention could be given directly or indirectly, verbally or non-verbally (Endriani, 2018). In addition, teachers could make students understand by provided explanations to students (Barlenti et al., 2017). The teacher tried to tell them to install an application that did not spend much the Internet quota. Only allow them to send assignments to WA because they did not have enough quota. Macharia and Pelser (2012) stated that learning materials using high-level technology complement intuition that affected student's recognition of e-learning. Teaching with technology could increase motivation.

\section{CONCLUSION AND SUGGESTIONS}

The study concludes that strategies used by teachers were Google form, Google Meet, quizzes, and video. Google meet was found to be rarely used for online learning because most teachers only used online chat. In addition, teachers found some obstacles: they were internet connection, unresponsive students, and problems with the operation of the equipment at the beginning of the pandemic.

EFL teachers were suggested to learn more online teaching strategies. The teachers were suggested to explore and develop online teaching strategies that were suitable for the students. Further study was suggested to investigate how online teaching strategies affect the success of learning. It was also suggested to explore the other problems that the teachers encountered during the online teaching process. 


\section{REFERENCES}

Agustina, L., \& Rusmana, I. M. 2020. Pembelajaran Matematika Menyenangkan dengan Aplikasi Kuis Online Quizizz. Jurnal Prosiding Sesiomadika, 2(1A),1-7.

Akhdar, A. 2006. Reality of the Use of Computers and Obstacles to their Use in Al Amal Academies' and Programs' Elementary Level Curricula, MA thesis (Unpublished MA thesis). King Saud University, Kingdom of Saudi Arabia.

Almurashi, W.A. 2016. The Effective Use of Youtube Videos for Teaching English Language in Classroom as Supplementary Materials at Taibah University in Alula. International Journal of English Language and Linguistics Research. (3), 32- 47.

Atsani, L. G. M. Z. 2020. Transformasi media pembelajaran pada masa Pandemi COVID-19. Al-Hikmah: Jurnal Studi Islam, 1(2), 44-54.

Barlenti, I., Hasan, M., \& Mahidin, M. 2017. Pengembangan LKS Berbasis Project Based Learning untuk Meningkatkan Pemahaman Konsep. Jurnal Pendidikan Sains Indonesia (Indonesian Journal of Science Education), 5(1), 81-86.

Chen, C. C., Wu, J.,Yang, S. C. 2006. The efficacy of online cooperative learning systems, the perspective of task-technology fit. Campus-Wide InformationSystems, 23(3). https://doi.org/10.1108/10650740610674139

Covey, S.1990. The 7 Habits of Highly Effective People. New York: The Free Press.

Cuban, L. 2018. The Flight of a Butterfly or the Path of a Bullet? Using Technology to Transform Teaching and Learning. ERIC.

Effendy, O.U. 2011. Ilmu teori dan filsafat komunikasi. Bandung: PT Citra Aditya Bakti. Perlindungan Siswa Indonesia.

Istiningsih, S., \& Hasbullah, H. 2015. Blended Learning, Trend Strategi Pembelajaran Masa Depan. Jurnal Elemen, 1(1), 49. https://doi.org/10.29408/jel.v1i1.79

Lestyanawati, R., \& Widyantoro, A. 2020. Strategies and Problems Faced by Indonesian Teachers in Conducting E- Learning System During COVID-19 Outbreak. Journal of Culture, Literature, Linguistic and English Teaching, 2(1), 71-82.Moleong, L. J. (2014). Metode Penelitian Kualitatif. Bandung: Remaja Rosdakarya.

Macharia, J. K., Pelser, T. G. 2012. Key factors that influence the diffusion and infusion of information and communication technologies in Kenyan higher education.Studies in Higher Education, (ahead-of-print), 1-15.

Miles, Huberman and Saldana. 2014. Qualitative Data Analysis: A Methods Sourcebook. Sage Publication.

Moloeng, L. J. 2014. Metodologi Penelitian Kualitatif. Remaja Rosdakarya

Moorhouse, B. L. 2020. Adaptations to face-to-face initial teacher education courses "forced" online due to the COVID-19 pandemic. Journal Education for Teaching: International $\begin{array}{llll}\text { Research and Pedagogy, 46(3), } & \text { 1-3. }\end{array}$ https://doi.org/https://doi.org/10/1080/02607476.2020.1755205

Purba, Leony Sanga Lamsari. 2019. Peningkatan konsentrasi belajar mahasiswa melalui pemanfaatan evaluasi pembelajaran quizizz pada mata kuliah kimia fisika I. Jurnal Dinamika Pendidikan, 12(1), 29-39.

Satrianingrum, A. P., \& Prasetyo, I. 2020. Persepsi Guru Dampak Pandemi Covid-19 terhadap Pelaksanaan Pembelajaran Daring di PAUD. Jurnal Obsesi: Jurnal Pendidikan Anak Usia Dini, 5(1), 633. https://doi.org/10.31004/obsesi.v5i1.574

Taufik, A. 2019. Perspektif tentang perkembangan sistem pembelajaran jarak jauh di Kabupaten Kutai Kartanegara Kalimantan Timur. Jurnal Pendidikan: Riset Dan Konseptual, 3(2), 88-98.

Warsita, B. 2014. Pola kegiatan pembelajaran jarak jauh. Jurnal Teknodik, 18(1), 73-83. 
Wijayanti, A, Safitri, P. T, \& Raditya, A. 2018. Analisis Pemahaman Konsep Limit ditinjau dari Gaya Belajar Interpersonal. Prima: Jurnal Pendidikan Matematika, 2(2), 157-173.

Windiarti, S., Fadilah, N., Dhermawati, E., \& Pratolo, B. W. 2019. Teachers' Perception toward the Obstacles of E-Learning Classes. Ethical Lingua: Journal of Language Teaching and Literature, 6(2), 117-128. https://doi.org/10.30605/25409190.v6.117-128

Wlodkowski, R. J. 2005. Adults in Modern Society are on a Lifelong Educational Journey. Available from http://userpages.umbc.edu/ koconne1/605TheAdultLearner/elearning.htm

Wong, L.-H., Looi, C.-K. 2011. What seams do we remove in mobile-assisted seamless learning? A critical review of the literature. Computers \& Education, 57(4), 2364-2381. https://doi.org/10.1016/j.compedu.2011.06.007

Yana, A.U. dkk. 2019. Analisis Pemahaman Konsep Gelombang Mekanik Melalui Aplikasi Online Quizizz. Jurnal Pendidikan Sains Indonesia. 7, (2), 143-152. 